\title{
POLAND'S FOREIGN AND SECURITY POLICY: MAIN DIRECTIONS
}

\author{
Agnieszka Bieńczyk-Missala ${ }^{1}$ \\ University of Warsaw
}

\begin{abstract}
:
This article tries to present the main areas of Polish foreign and security policy.Poland's membership in the EU and in NATO was the strongest determinant of its position in international relations, and the guiding light of its foreign policy. Poland's work in the EU was focused in particular on EU policy towards its eastern neighbours, common energy policy and security issues, while in NATO, Poland has always been a proponent of the open doors policy and has maintained close relationship with the US, supporting many of its policies and initiatives.
\end{abstract}

Keywords: Poland, European Union Security and Defence, NATO, Poland's bilateral relations.

\section{Resumen:}

El artículo presenta las principales áreas de la politica exterior y de seguridad de Polonia, siendo su pertenencia a la Unión Europea y la OTAN los principales determinantes de su posición en las relaciones internacionales y el foco que ilumina su politica exterior. La política y actividades en la Unión Europea se han centrado en particular en la política hacia sus vecinos del Este, mientras que en La OTAN, Polonia ha sido un defensor continuamente de la política de puertas abiertas y ha mantenido una relación muy estrecha con los Estados Unidos, apoyando sus políticas e iniciativas.

\section{Palabras clave: Polonia, Seguridad y Defensa de la Unión Europea, OTAN, Relaciones} bilaterales de Polonia.

Copyright $(\mathcal{C}$ UNISCI, 2016.

Las opiniones expresadas en estos artículos son propias de sus autores, y no reflejan necesariamente la opinión de UNISCI. The views expressed in these articles are those of the authors, and do not necessarily reflect the views of UNISCI.

\footnotetext{
${ }^{1}$ Agnieszka Bieńczyk-Missala is Assistant Professor of Strategic Studies at the Institute of International Relations, University of Warsaw

Email: Agnieszka.Missala@uw.edu.pl.

http://dx.doi.org/10.5209/rev_RUNI.2016.n40.51808
} 


\section{Internal and External Aspects ${ }^{2}$}

Starting in 1989, Poland successfully transformed its political system from an undemocratic regime into a democracy. The principles of democratic order, the rule of law, respect for human rights and solidarity became the foundations of the state. Poland became a member of the Council of Europe (1991), the World Trade Organization (1995), and the Organization for Economic Co-operation and Development (1996). The crowing accomplishment of Polish foreign policy was the country's accession to NATO in 1999 and to the European Union in 2004, followed by joining the Schengen Area in $2007^{3}$.

Poland's membership in the EU and in NATO was the strongest determinant of its position in international relations, and the guiding light of its foreign policy. Under the 1997 constitution, the objectives of Poland's foreign policy were to safeguard the sovereignty of the state, its security and the integrity of its territory. NATO was the best choice for Poland to develop the security policy in cooperation with the United States. The EU, on the other hand, provided the means and opportunities for a rapid general development of the country. Thanks to EU funds and policies, alongside to the new opportunities in communications, infrastructure, trade, education, and other areas, the modernization of the country took place. In the first decade of Poland's membership in the EU, the country's GDP increased from PLN 884 billion to PLN 1600 billion, and Poland reached the level of over $60 \%$ of the EU's level of economic development ${ }^{4}$. Investment capital rushed in, amounting to over PLN 405 billion in the period 2004-2013. Export of goods and services to the West tripled, what resulted generating a surplus of approx. PLN 100 billion ( $€ 28.8$ billion ) in $2014 .^{5}$ While it was certainly possible to make better use of EU funds, the above-cited numbers - alongside the steady economic growth ${ }^{6}-$ meant that Poland was considered a leader among the 'new' EU member states. Nevertheless, it didn't enter the Eurozone.

In the same period, the public debt increased significantly, from PLN 431,4 billion in 2004 to PLN 780 billion in 2015. Compared to other European countries, Poland is also lagging behind in terms of compensation for work. Average monthly earnings went up from EUR 530 in 2004 to over EUR 1000 euro in March 2014 in the business sector. However, average earnings in Poland (in USD) amount to just over $32 \%$ of that of Germany, $31 \%$ of France, $26 \%$ of United Kingdom and $41 \%$ of Spain (134\% of that of Hungary) $)^{7}$. This has created a powerful social frustration, powering economic migration on a drastic scale. In 2004-2014, almost 1.8 million Poles left the country. Given the country's birth rate of $9,97^{8}$, this has exacerbated the demographic problems. Poland also continues to struggle with certain

\footnotetext{
${ }^{2}$ This text is not an exhaustive presentation of Poland's foreign policy. Rather, it offers a general overview of its main areas and issues. Poland is a mid-sized Central European country bordered by large neighbours. As such, it focuses on pursuing its interests mainly within Europe. Because it has undergone a successful democratic transformation, and because it has been incorporated into European and trans-Atlantic political and organizational structures, it firmly belongs to the conceptual West. Its foreign policy is predictable. The conservative government of Law and Justice is not going to change the fundamental objectives and directions of Polish foreign policy. It will however likely change the style in which politics is conducted and shift emphasis towards issues that are not currently at the foreign policy forefront.

${ }^{3}$ On the process of reorientation of Poland's Foreign Policy see: Kuźniar, Roman (2009): Poland's Foreign Policy after 1989, Warsaw, Widawnictwo Naukowe Scholar.

${ }^{4}$ Rzeczpospolita, 9 May 2014.

${ }^{5}$ According to the Polish Ministry's of Foreign Affairs Note on The Economic and Social Effects of the Polish Membership in European Union, in connection with the eleventh anniversary of accession and Polish accession to the EU,at https://www.msz.gov.pl/resource/26c005f4-b73e-4402-bb32-8b10c1b42a4c:JCR (data dostępu: 24 stycznia 2016).

${ }^{6}$ Poland is the only EU member state that has recorded economic growth year-on-year every year after 2008.

${ }^{7}$ Data of 5 May 2015, at http://www.bankier.pl

${ }^{8}$ Birth/1.000 population.
} 
challenges. In the Global Innovation Index 2009-2010, Poland ranks poorly at 47, despite its economy being ranked at a much better position (20).

While euroscepticism is on the rise in Europe (largely due to the financial crisis of 2008), Poland and the Polish society have remained greatly enthusiastic towards the EU, becoming one of Germany's strongest allies in its efforts towards reform and further integration. Support for Poland's membership in the EU is at the level of $72 \%{ }^{9}$.

As a member of NATO and the EU, Poland was located at their borders, a strong determinant of its foreign policy. With regard to the neighbouring countries of Ukraine and Belarus, Poland's policy objective was to foster democratization and the promotion of improved relations with Western institutions. Relations with Russia continued to present the greatest challenge. This was due to two reasons: firstly, problems rooted in the period before 1989, when Poland was part of the Eastern block controlled by the USSR and Poland's reorientation, and, secondly, the different visions for the future of post-Soviet states. While Russia pursued a future in which these countries were in its sphere of influence, Poland made efforts to bring them as close as possible to the West.

In the 1990s, the pursuit of foreign policy objectives in Poland was facilitated by a consensus worked out by all the political parties on the integration into the Western institutions and normalization of relations with Poland's neighbours to the east. After the EU accession, gradually differences began to emerge between the most influential political parties: Civic Platform (Platforma Obywatelska) and Law and Justice (Prawo i Sprawiedliwość). Both of these parties agreed that membership in NATO and the EU provided the foundation of security and development of the country, and both were in favour of strengthening relations with the United States. However, they differed in their approaches to the manner in which foreign policy should be implemented, and which issues should prevail. The Law and Justice administration in 2007-2008 and later after 2015 was and is eurosceptical, distrustful towards Germany, and with very limited initiatives in the relations with Russia. On the other hand, policy making of the Civic Platform's administration in 20082015 was strongly pro-European.

Institutionally, foreign policy in Poland is the responsibility of the government, headed by the prime minister. Foreign policy is coordinated by the foreign minister, but the president also has the right to become involved. As a representative of the state in its external relations, the president is expected to cooperate in this area with the prime minister and the foreign minister.

Formally, a document entitled Foundations of Poland's foreign policy, approved by the government at the request of the foreign minister, forms the basis of Poland's foreign policy. The Foundations... serves as guidelines for the government departments as they develop their own foreign cooperation plans. Every year, the foreign minister presents a report to the Parliament (entitled Information on foreign policy), outlining the key policy objectives ${ }^{10}$.

\section{Poland in the European Union}

Poland's accession to the EU triggered a fundamental reorganization of the country's foreign

\footnotetext{
9 "European Youth in 2014", Eurobarometer, p.11.

10 In March 2012, the Council of Ministers adopted the Priorities of Polish foreign policy, the first long-term strategy paper on foreign policy (including European policy) since 1989. This key document guides the Polish diplomacy in its operations. Its purpose is to coordinate the work of the administration with regard to external relations. Moreover, it presents to the general public the vision and key objectives for Polish foreign policy up to 2016.
} 
policy. A full mobilization for the foreign service and multiple adaptation of ministry structures were necessary to meet the challenges resulting from the membership ${ }^{11}$.

The first years in the EU made it evident that Poland had no clear vision of the future of the Union. It took time for the country to gain experience and develop a constructive approach to policy within Europe. The EU membership in itself was a huge adjustment for Poland, which was not immediately ready to discuss further stages of European integration. There was a concern that the EU might become dominated by the largest member states ${ }^{12}$. The Polish government supported a vision of a European Union of sovereign member states rather than a federation of states.

This approach was reflected in the country's position during the drafting of the Treaty Establishing a Constitution for Europe ${ }^{13}$ and of the Lisbon Treaty thereafter. Polish leaders in general, and President Lech Kaczyński in particular, were reluctant to accept the Lisbon Treaty, expressing hesitation as to whether it was at all necessary. Poland opposed the efforts to boost the powers of European institutions, including the proposal to appoint a president of the European Council and to uphold the principle of 'one state - one commissioner' for the European Commission. It also protested against the changes in the decision-making system unfavourable for small and medium-sized countries (where a decision would require a majority of $55 \%$ countries and $65 \%$ of their population). It pursued the strengthening of cooperation on European Security and Defence Policy and an expansion of the solidarity clause to also cover energy security.

Poland only ratified the Lisbon Treaty after the second Irish referendum, on 10 October $2009^{14}$. As a result, it was viewed as a country for which European cooperation is not a priority. This image was further reinforced by Poland's support for an involvement in the war in Iraq, criticized by countries such as Germany and France. The prevalent view in Poland, however, was that Polish security interests require close cooperation with the United States, including ventures as controversial as the war in Iraq, due to a variety of reasons (including the belief that EU's defence capacity is insufficient).

The government formed by the Civic Platform and the Polish People's Party (Polskie Stronnictwo Ludowe), which was in power for two terms of office in 2008-2015, endeavoured to shift the perception of Poland within the EU. When the new foreign minister Radosław Sikorski presented his first foreign policy report to the Sejm on 7 May 2008, he declared that his first priority would be to make Poland 'strong with the strength of European Union's solidarity', and he went on to speak at length about the EU, saying for example: "The European Union is not the dangerous "them", Europe and the Union is just "us", 15 . In his address to the Sejm on 29 April 2012, he said that Poland supports an EU where the member states are forever sovereign and maintain the right to leave the Union, as well as the right to determine the powers transferred to the community. He argued in favour of a 'smart federation', which would be a 'way towards a greater power, built together, and not towards a loss of identity ${ }^{\prime 16}$. Polish foreign policy continued in this spirit for the next seven years, to the

11 The government proposed the bill on the coordination of matters related to the membership of the Republic of Poland in the European Union relatively late, in December 2008. The main change resulting from the bill was the merging of the Committee for European Integration with the Ministry of Foreign Affairs.

12 International Herald Tribune, 14 August 2007.

13 Poland participated in the negotiations since 2003.

14 The constitutional treaty was rejected in the referendums in France and in the Netherlands.

15 Information by the Foreign Minister on foreign policy of the Republic of Poland in 2008, at www.msz.gov.pl 16 Information by the Foreign Minister on the guidelines of Polish foreign policy in 2012, presented to the Sejm on 29 April 2012, at www.msz.gov.pl. 
dissatisfaction of the Law and Justice party (in parliamentary opposition) ${ }^{17}$. It resulted in the appointment of Donald Tusk to serve as the President of the European Council in August 2014.

Poland's work in the EU was focused in particular on EU policy towards its eastern neighbours, common energy policy and security issues. Poland's most important initiative, put forward jointly with Sweden, was the Eastern Partnership, approved on 19 June 2008 by the European Council. Its objective was to bring about closer cooperation between the EU and Georgia, Moldova, Armenia, Azerbaijan and Belarus (on the condition that the latter chooses to begin the process of democratization). The objective of the Eastern Partnership was to develop a mechanism for permanent institutional cooperation in the following areas: politics, security, economy, social issues, financial issues, environmental issues, borders, and the movement of persons ${ }^{18}$. The project was formally launched at a special Eastern Partnership summit in the spring of 2009. Foreign minister Radosław Sikorski made it clear that the goal of the Eastern Partnership was to help the participating countries meet the criteria for EU membership. He announced that it was going to be 'a Polish brand in the EU and a priority of the Polish presidency in $2011^{, 19}$.

Poland systematically supported the development of the Eastern Partnership. It launched numerous initiatives, such as the establishment of a 'group of friends' of the Partnership, organization of the September 2011 summit, and founding the Public Administration Academy of the Eastern Partnership in Warsaw. Poland has also provided bilateral counsel services, used primarily by Moldova, Ukraine and Georgia, and made efforts to ensure that Eastern Partnership issues are included in the scope of powers of a EU commissioner ${ }^{20}$.

The Eastern Partnership was also used to develop diplomatic cooperation with Sweden and Germany (from which the project had garnered strong support). Bi- and trilateral visits in Eastern Partnership countries were held relatively often. Additionally, Poland started a parallel project: the European Endowment for Democracy, first proposed by Radosław Sikorski in January 2011, and then launched during Poland's EU presidency. The fund was designed to support organizations and individuals in EU's eastern and southern neighbouring states working in the area of advancing democracy ${ }^{21}$. Poland has been one of the largest contributors to the fund, providing EUR 5 million by 2015.

Polish diplomacy was also hard at work on the issue of energy solidarity. This is due to the country's strong dependence on Russian oil and natural gas. In 2006, approx. $91.5 \%$ of imported natural gas came from countries situated east of Poland, including $68.2 \%$ from the Russian Federation. There were several aspects of Poland's energy policy. Firstly, Poland supported the development of a common energy policy for the entire EU. Secondly, it

17 Law and Justice argued that a tighter political union would weaken the states and thus the entire European Union, and also cause the 'reign of the more powerful'. See: Transcript of the eleventh sitting of the Sejm of the Republic of Poland, 29 March 2012, Warsaw 2012.

18 The project gained popularity in the European Union after the war between Russia and Georgia, and after the 'gas crisis' between Russia and Ukraine. These events demonstrated to the European Union that there was a need for action that would encourage democratization and stabilization in the states neighbouring it to the east. See also: Eastern Partnership: Communication from the European Commission to the European Parliament and the Council, COM(2008) 823, 3 December 2008.

${ }^{19}$ Lecture by Radosław Sikorski in the European Policy Center, 26 May 2008, at http://www.epc.eu

${ }^{20}$ Eventually, this responsibility was given to the European Commissioner for Enlargement and European Neighbourhood Policy Štefan Füle; see also: Ochmann, C.: "Przyszłość Partnerstwa Wschodniego z niemieckiej perspektywy", Biuletyn niemiecki No 6, 13 May 2010.

${ }^{21}$ See also: Biuletyn PISM No 93, 7 October 2011. 
endeavoured to discourage Germany and Russia from building the North European pipeline. Thirdly, it focused on seeking out alternative energy sources and ensuring reliable supplies ${ }^{22}$.

Poland and Ukraine pay the highest prices for the Russian natural gas in all of Europe. Therefore, Poland was interested in the potential development of a common energy supply system and pursued a broader energy solidarity clause for the EU. Poland's position was that the clause should become applicable when one member state loses access to natural gas. It argued that developing a common energy market helps to diminish the risk of potential blackmail of Eastern European countries by Russia and thus of the entire EU becoming entangled. Once the conflict in Ukraine began in 2014, the matter took on an extra urgency for Poland. Poland took decisive steps towards developing the energy union, with a vision far exceeding the EU. The following elements were proposed: development of energy infrastructure between EU member states and their neighbours; solidarity mechanisms in case of a supply crisis; using the bargaining power of the entire EU in negotiations with suppliers; using domestic energy sources; diversification of supply sources; working to strengthen the energy security of the states neighbouring the EU. Most of these elements were incorporated into the energy union strategy presented by the European Commission on 25 February 2015. However, the strategy contains no hard language on joint (shared) natural gas purchases in the future.

Due to its history and geopolitical location, Poland's foreign policy has always been strongly focused on security issues. The question of the EU's ability to guarantee security, along with its defence potential, has been at the forefront of concern for every government. National security strategy documents adopted in 2007 and 2014 both supported the development of a European security policy. ${ }^{23}$ In the Lisbon Treaty, Poland was a proponent of the provision demanding solidarity in defence matters (188c). It also supported the advancement of the security and defence policy proposed by France during its presidency in 2008, and on numerous occasion advocated a revision and redevelopment of the security and defence policy of the EU.

The events of 2015 undermined the image of Poland as a pro-European country that observes the principle of solidarity in the face of EU-wide challenges. Two factors were instrumental in this process:

Firstly, Polish authorities were sceptical towards the unconditional welcome extended towards the masses of refugees and migrants (in particular by Germany). In defence of its position, Poland mentioned the increased immigration for Ukraine. According to Eurostat data, Poland absorbed the second-largest number of Ukrainian immigrants (after Great Britain): an estimated 355,4 thousand people in $2014^{24}$. At the end of 2015 , it was estimated that over 800,000 immigrants had found work in Poland. Security and cultural factors were also invoked. Pressured and criticized by the EU, which argued that Poland was violating the solidarity principle, the country eventually agreed to accept 7,000 refugees, while continuing to uphold its opposition towards fixed mandatory quotas for redistribution of the incoming refugees.

\footnotetext{
${ }^{22}$ Poland has cooperated in this respect with Qatar and the United States. In 2016, facilities for handling imported natural gas were launched in Świnoujście. PKN Orlen, a Polish investor, also acquired the refinery Możejki Nafta, but in July 2007 Russia cut off its oil supply along the Friendship Pipeline.

${ }^{23}$ National security strategy of the Republic of Poland (Strategia bezpieczeństwa narodowego Rzeczpospolitej Polskiej), Warsaw 2007; National security strategy of the Republic of Poland (Strategia bezpieczeństwa narodowego Rzeczpospolitej Polskiej), Warsaw 2014.

24 Eurostat report 2014.
} 
Secondly, after eight years of coalition government of the Civic Platform and the Polish People's Party, the parliamentary election held on 25 October 2015 brought the conservative Law and Justice into power. In the electoral campaign, the party had focused on changes in Poland's internal affairs. Once in power, it adopted new laws designed to circumnavigate the constitutional order. The changes heavily affected the functioning of the Constitutional Court and the National Broadcasting Council (the body in charge of the public media), which led to protests across the country. International institutions (the European Commission, the European Parliament, the Council of Europe and the Organization for Security and Cooperation in Europe) took an interest in the developments.

The European Commission decided to launch the EU's Rule of Law Mechanism in order to assess the situation in Poland ${ }^{25}$. Moreover, on 19 January 2016 the European Parliament held a debate on the situation in Poland, attended by the new Prime Minister Beata Szydło. She argued that the changes in Poland are in line and fully compliant with European law and that they constitute an internal matter of Poland ${ }^{26}$.

In response to the tensions between Poland and the EU institutions, on 23 January 2016 foreign minister Witold Waszczykowski published an article "What Union does Poland want?". The article posits that Poland remains open to dialogue within the EU and promises that it will be an active and responsible member of the EU. Yet it also argues against a supranational, federalized Europe, and advocates the right of individual countries to take decisions that directly concern their own citizens ${ }^{27}$.

\section{Polish Security Policy}

Before the annexation of Crimea by the Russian Federation and the 2014-onwards conflict in Ukraine, Poland's security situation was considered to be much better than in any other period of its history. There were no border disputes; relations with all neighbours were good; the risk of possible aggression against Poland was also considered minimal. Since 2014, Poland has focused on strengthening its security policy. Poland's security budget is $1.8 \%$ GDP, one of the highest proportions in Europe. There was a plan to raise this figure to 2\% starting in 2016, but the new Law and Justice administration has put these plans on hold. The main pillars of Poland's security policy are as follows: NATO, the EU, cooperation with the United States, participation in regional and global organizations such as the Organization for Security and Cooperation in Europe, Visegrád Group and the United Nations ${ }^{28}$.

NATO and the guarantees of Article 5 of the North Atlantic Treaty remain at the core of 'hard security' policy. The NATO membership gave Poland access to the largest and stronger military organization in the West (mainly thanks to the participation of the United States) ${ }^{29}$. Poland has been an active member of the alliance, continually engaging in its various efforts to adapt to the changing circumstances. It participated in the NATO operation in Kosovo

25 College Orientation Debate on Recent Developments in Poland and the Rule of Law Framework: Questions\&Answers, European Commission Fact Sheet, Brussels, 13 January 2016.

26 Poland: MEPs Debate Rule of Law Issues with Prime Minister Szydto, European Parliament Press Release, 19 January 2016; Full statement at http://www.europarl.europa.eu/news/en/news-room/20160114IPR09899/PolandMEPs-debate-rule-of-law-issues-with-Prime-Minister-Szyd $\%$ C5\%82o .

27 The article was published in a number of papers including Frankfurter Allgemeine Zeitung, Corriere della Sera and Die Presse dated 23 January 2016.

28 National security strategy of the Republic of Poland (Strategia bezpieczeństwa narodowego Rzeczypospolitej Polskiej), Warsaw 2014.

29 M. Madej, "Polska w systemie bezpieczeństwa międzynarodowego" (in:) S. Bieleń, Polska w stosunkach międzynarodowych, Warsaw 2007, p. 41. 
(from 1999 onwards), Bosnia and Herzegovina (1995-2004), Macedonia (2001-2003) and Pakistan (2005-2006). It was also involved in the operation in Afghanistan launched in 2001 under Article 5 of the Treaty in response to the terrorist attacks in the United States on 11 September 2001. Since January 2015, Polish military personnel have provided training as part of Resolute Support Mission in Afghanistan. Periodically, Poland has also been involved in the anti-terrorist maritime operation Active Endeavour and Baltic Air Policy, the objective of which is to monitor the air space above Lithuania, Latvia and Estonia.

On the other hand, Poland did not participate in the NATO operation in Libya in 2011. Polish authorities have argued that there are insufficient grounds for NATO involvement in North Africa and said it was necessary to find a balance between reinforcing NATO's defence potential and undertaking missions beyond its territorial reach ${ }^{30}$.

As for the future development of NATO, Poland has always been a proponent of the open doors policy. It supported the membership of the Balkan countries and promoted the NATO aspirations of Georgia, Moldova and Ukraine. After the challenging and expensive operation in Afghanistan, Poland has advocated for a balanced approach to external operations and defence capacities (having made similar entreaties at the NATO summits in Lisbon in 2010 and in Chicago in May 2012) ${ }^{31}$.

With the military operations in Ukraine, the unprecedented incidents involving Russian airplanes over the Baltic Sea, and the increasingly hostile rhetoric between Russia and NATO, security has become the chief preoccupation of Polish authorities. There have been suggestions of requesting permanent NATO detachments in Poland. They met with opposition from Germany and France, and with scepticism from the United States. Poland has therefore pursued a formula in which NATO troops would be stationed in the country on a rotating basis. At the NATO summit in Newport on 4-5 September 2014, Poland's proposal garnered support from the Baltic States, Romania and Bulgaria. Poland has also been actively investigating new avenues for increasing NATO's defence capacity eastwards. It argued in favour of conducting the allied forces' drills in Poland and the Baltic states, and of locating new logistics centres and emergency warehousing facilities in these territories. Poland was a proponent of reforming the NATO Response Force, including the establishment of the highreadiness 'spearhead force' and strengthening the Multinational Corps Northeast in Szczecin, staffed mainly by personnel from Poland, Germany and Denmark. Discussions on these issues will continue at the NATO summit in Warsaw in July 2016.

The United States was Poland's key partner for bilateral cooperation on security matters. Because of American support when it was seeking NATO membership ${ }^{32}$, Poland in turn supported various American initiatives, e.g. the military intervention in Iraq in 20032008, and was an active member of the anti-terrorist coalition. Even as the political parties in power change, Polish authorities have continued to maintain close ties with the United States and have sought American involvement in modernizing the Polish armies. There was observable anxiety in the beginnings of Barack Obama's administration when it seemed that the United States was losing its interest in Europe.

30 After the engagements in Iraq and Afghanistan, attempts were made to rationalize the approach to deploying Polish military units. In light of the casualties among Polish soldiers in Afghanistan, the public opinion was opposed to participation in the intervention in Libya. See the remarks by President Bronisław Komorowski on 17 Match 2011, news archive at www.prezydent.pl

31 For more information see the interview with the advisor to the President of the Republic of Poland Roman Kuźniar, Polityka dated 16 May 2012; see also: P. Pietrzak, „Szczyt NATO w Chicago - determinanty, oczekiwania i rezultaty", Bezpieczeństwo Narodowe (kwartalnik BBN) 2012, No 22.

${ }^{32}$ Winid Bogusław: "Security Issues in Polish-American Relations", in Kuźniar Roman (ed.): Poland's Security Policy 1989-2000, Warsaw 2001, p. 171-193. 
Despite the deal between Poland and the United States (signed during the presidency of George W. Bush on 20 August 2008) to base interceptor missiles in Poland as part of the American anti-missile shield, Barack Obama was reluctant to proceed with this plan. ${ }^{33}$ Instead, he modified the project to cover the entire NATO. The new concept (referred to as the European Phased Adaptive Approach) envisaged four stages of anti-missile defence, including the new generation SM-3 defences against short- and medium-range missiles, to be placed on the ground by approx. 2018. ${ }^{34}$ Polish authorities have expressed interest in joining the program. A protocol amending the Agreement between the Government of the Republic of Poland and the Government of the United States of America on deployment on Polish territory of anti-ballistic missile interceptors, drafted in Warsaw on 20 August 2008, was signed on 3 July $2010^{35}$.

Poland also arranged for American military personnel to provide training locally. Under the above-mentioned Protocol, from November 2012 onwards a detachment of American troops has been based in 32nd Air Base in Poland to contribute to training programs and drills.

Cooperation grew even tighter when the war in Ukraine started. During his visit to Poland in June 2014, President Barack Obama invoked Article 5 of the North Atlantic Treaty and said he had come to Warsaw 'on behalf of the United States, on behalf of the NATO Alliance - to reaffirm our unwavering commitment to Poland's security', adding that 'Poland will never stand alone ${ }^{36}$. Polish authorities had expected and welcomed words to this effect.

On 17 April 2014, Polish defence minister, Tomasz Siemoniak, and American Secretary of Defense, Chuck Hagel, launched a joint solidarity and partnership roadmap. The roadmap proposes permanent presence of American detachments (on a rotating basis) in Poland, more training programs and drills and increased cooperation across all branches of the military. Moreover, at President Barack Obama's request, the American Congress approved additional funding of up to a billion USD for joint projects. Due to the conflict across Poland's eastern border, the scale of consultations and joint training exercises has been unprecedented.

As a great supporter of the development of the European Security and Defence Policy, Poland was engaged in the work of the European Defence Agency and missions (both civilian and military) of the EU. It was involved in the establishment of EU rapid deployment battlegroups, and itself participated in the international battlegroup (with Germany, Slovakia, Lithuania and Latvia) in 2007, in the Weimar Battlegroup with Germany and France in 2013 and the Visegrád Battlegroup with the Czech Republic, Slovakia and Hungary in 2016.

\footnotetext{
33 Górka-Winter Beata: "Porozumienia Polski i Stanów Zjednoczonych w sprawie obrony przeciwrakietowej zakres współpracy i perspektywy realizacji", Biuletyn, 22 August 2008.

34 See also: Górka-Winter, Beata: "Program obrony przeciwrakietowej - nowe założenia administracji Baracka Obamy", Biuletyn PISM, No 52 (584), 10 September 2009.

35 In 2010, Strategic Dialogue and Strategic Cooperation Consultative Group continued to hold meetings (it had been established on the basis of the August 2008 Declaration on Strategic Cooperation). Strategic dialogue was also renewed in connection with the visit to the United States of foreign minister Radosław Sikorski with an official delegation in May 2010.

36 Remarks by President Obama at 25th Anniversary of Freedom Day, Warsaw, 4 June 2014, at http://photos.state.gov/libraries/poland/788/pdfs/PresidSpeechAmended_PL.pdf,

https:/www. whitehouse.gov/the-press-office/2014/06/04/remarks-president-obama-25th-anniversary-freedomday.
} 
Recently, Poland has also participated in military EU missions in Chad and the Central African Republic, a training mission Mali, and in operation Althea, i.e. the EU operation in Bosnia and Herzegovina ${ }^{37}$.

Poland has no direct political or economic interests in Africa, but it has acted on the belief that standing in solidarity with the EU member states gives it a moral right to ask for greater involvement of the EU in promoting security, stability and the rule of law to the east of the Polish border, should such a need arise ${ }^{38}$. Poland was disappointed with the EU's lukewarm response to the war in Ukraine in terms of security policy, and thus it has increased its efforts to have NATO bases established in its territory.

\section{Bilateral Relations with EU Member States}

Poland has maintained good bilateral relations with all EU member states. Germany, Poland's largest neighbour ${ }^{39}$ and biggest trading partner ${ }^{40}$ has been particularly important in this respect. Re-orientation of the Polish foreign policy post-1989, Poland's support for the reunification of Germany and Germany's support in the 1990s of Poland's effort to develop good relationship with Western institutions provided a good foundation for political and economic cooperation. Given the two countries' complicated history, the process of reconciliation was particularly noteworthy. It was rendered possible by the fact that both countries embraced democracy, human rights and a pro-European attitude as cornerstones of their policy.

Dialogue between Warsaw and Berlin and their cooperation within the EU was reinforced by the mechanism of Polish-German Intergovernmental Consultations. Bilateral relations further flourished during the financial crisis in Europe after 2008, as Polish-German dialogue played a significant role in drafting EU-wide reform plans. Poland's enthusiasm towards reforms provided a counterweight to Germany's poorly-received attitude, while Germany provided support in budgetary matters.

Germany was also an important ally in promoting democracy in Ukraine and Belarus, and in shaping the policy of EU sanctions towards Russia after the annexation of Crimea in 2014. In the recent years, foreign ministers of Poland and Germany have travelled together to Ukraine, Georgia and Moldova and issued joint statements. In February 2014, along with the French foreign minister, they held mediation in Ukraine that helped end the violence in Maidan in Kiev. On 26 November 2014, Radosław Sikorski and Guido Westerwelle issued a declaration in support of 'a European future for Ukraine' ${ }^{41}$. However, in the following months critical opinions were voiced in Poland - to the effect that Germany made an unsatisfactory

\footnotetext{
${ }^{37}$ Poland decided against participating in the NATO operation against Libya in 2011, despite the suggestions from France that it should became involved. Following the costly operations in Afghanistan and Iraq, it was a time of a more moderate approach of the Polish administration towards Polish participation in missions abroad. There were also considerations with regard to the need to invest in Poland's defence potential.

${ }^{38}$ Information presented by the Ministry of National Defence with regard to the framework and preparation of the mission of the Polish Military Contingent in Chad, presentation by Stanisław Komorowsk, undersecretary of state at the Ministry of National Defence, before the National Defence Committee of the Sejm, 10 January 2008, Biuletyn No 151/VI.

39 The following two legal acts in particular outline the legal basis for the relations between the two countries: (1) the treaty acknowledging the existing border dated 14 November 1990, (2) the treaty on neighbourly policies and friendly cooperation dated 17 June 1991.

40 See also an interesting analysis in: M.A Orenstein, "Sixth Market to Watch: Poland", Foreign Affairs January/February 2014.

41 See also the joint declaration by foreign ministers of Poland and Germany with regard to Ukraine dated 26 November 2013, news archive at www.msz.gov.pl
} 
effort in trying to ensure that Poland would have a seat at the table during the negotiations on Ukraine's future, held in Berlin in August 2014 and later in Minsk.

On many issues, the positions of Poland and Germany differed ${ }^{42}$. Poland was very critical towards the construction of the pipeline between Russia and Germany (Nordstream I) and the plans to follow up with Nordstream II. It cited the high costs of the investment and its negative environmental impact, and argued that it violated the principle of energy solidarity ${ }^{43}$. These investments were directly contrary to Poland's interest as a transit state and made it easy for Russia to blackmail Eastern European states (primarily Ukraine). Germany in turn was critical towards the (eventually dismissed) plans to build an American anti-missile system in Poland ${ }^{44}$, and towards Poland's efforts to ensure the location of NATO bases in its territory. Germany's unfavourable views on these two issues were perceived in Poland as obstinate unwillingness to recognize Poland's and Europe's fundamental security needs, and provided fuel for anti-German sentiments among political conservatives.

The influx of refugees and migrants that increased in 2015 also drove a wedge between the two countries. Poland's resistance to the idea of assigned quotas of refugees and migrants was perceived by Germany as a violation of solidarity.

History continues to be a stumbling block in Poland's relations with Germany. One of the most serious issues in the recent years has been the claims for compensation put forward by German compatriots' (local) associations. The ruling of the European Court of Human Rights dated 7 October 2008 on the inadmissibility of the application of Preußische Treuhand against Poland on the grounds of expropriation of property of Germans expulsed from Poland after World War II was an important factor in this regard. The Court held that the application against Poland was inadmissible because the borders were re-drawn and expulsions took place on the basis of decisions of the superpowers at the time ${ }^{45}$. This was fully in line with the official positions of both the Poland and the German government ${ }^{46}$. Negotiations pertaining to historical issues were conducted mainly in 2007-2015 by Władysław Bartoszewski, serving as Plenipotentiary of the President of the Council of Ministers for International Dialogue. Matters discussed during the negotiations included the artefacts stolen by Germans, claims with regard to the Prussian Library ${ }^{47}$ and the plans for the design and construction of the Centre Against Expulsions championed by the Federation of Expellees headed by Erika Steinbach. Concerns were voiced by the Polish government about a potential revisionist turn in German historical policy in connection with these issues ${ }^{48}$.

\footnotetext{
${ }^{42}$ Wóycicki, Kazimierz, Czachur, Waldemar: "Challenges for Poland's Policy Towards Germany", The Polish Quarterly of International Affairs, Vol. 18, No.1, p. 25-42.

43 Interview with Prime Minister Donald Tusk, Neue Osnabrücker Zeitung dated 6 September 2008.

44 The article authored by minister Frank-Walter Steinmeier and published in Sueddeutsche Zeitung on 4 February 2009 was received with astonishment in Poland. The article urged the United States not to place elements of the anti-missile system in Poland and the Czech Republic, in the interest of disarmament.

45 The United States, the Soviet Union, Great Britain and France.

46 See: Barcz Jan and Frowein Jochen A.: Expert opinion on claims related to World War II directed by German entities against Poland, drafted at the request of the governments of Germany and Poland, 2 November 2004, at http://www.pol-niem.pl/docs/47/ekspertyza.doc; Barcz Jan: "Long Shadow of History: On the Decision of the European Court of Human Rights of 7 October 2008", The Polish Quarterly of International Affairs, Vol. 18, No.1, p. 43-60.

47 The Polish Ministry of Foreign Affairs participated in the publication of a report on the war losses in Poland in 1939-1945 (Sprawozdanie $w$ przedmiocie strat i szkód wojennych Polski $w$ latach 1939-1945), published together with the Polish-German Reconciliation Foundation. It was a reprint of a report originally published in 1947; the new report was sent to diplomatic outposts in Warsaw, libraries and relevant research institutions. 48 M. Cichocki: "Widoczny znak - cudze zobowiązanie", Rzeczpospolita dated 5 February 2008, P. Semka, "Widoczny znak - mamy prawo do obaw", Rzeczpospolita dated 7 February 2008.
} 
Poland was also interested in developing bilateral relations with France. However, due to France's reserved attitude towards a variety of Polish movements (Poland's pursuit of EU membership, its involvement in the war in Iraq on the side of the United States, attempts at EU reform, attempts at adopting a EU constitution), bilateral relations were rather guarded ${ }^{49}$. When a declaration on Polish-French strategic partnership was signed on 28 May 2008, its content was not very solid.

Poland and France stood together with regard to the Common Agricultural Policy, advocating its further development. They also shared a vision for a Europe with greater security and defence capacity. For many years, Poland found it difficult to interest France in the problems of EU's eastern neighbours, given its vested interest in developing a neighbourhood policy to the south and in encouraging Poland's involvement in Africa. The latter efforts were generally successful, with the exception of the intervention in Libya in 2011. Polish Prime Minister Donald Tusk announced a new opening in Polish-French relations after François Hollande was elected President on 6 May 2012. The new president declared his support for Poland's initiatives in the EU and offered his assistance in budget negotiations ${ }^{50}$. An aspect to be emphasized is the support for sanctions against Ukraine once the violence broke out on the Maidan in 2013, and against Russia after the annexation of Crimea.

Apart from their bilateral relations, Poland, Germany and France maintained moderate activity levels within the framework of the Weimar Triangle. Poland in particular pursued these relations, which is perceived as potentially advantageous to its position in Europe. The formula of Weimar Triangle +, with representatives of Ukraine and Russia, also had Poland's support. Meetings at ministerial level took place practically every year. The last Weimar Triangle summit was held at the invitation of President Bronisław Komorowski in Warsaw in 2010, and it was attended by German Chancellor Angela Merkel and French President Nicolas Sarkozy. Topics under discussion within the Weimar Triangle included the Common Security and Defence Policy and the Eastern Partnership.

In seeking to meet its political and economic objectives in the EU, Poland has naturally turned towards the Central and Eastern European states that joined the EU at the same time in 2004. Because of their shared history, including their time in the Eastern block during the Cold War, this seemed like a promising solution. Poland arranged regular bilateral meetings with the countries in the region. Additionally, it formed the Visegrád Group together with the Czech Republic, Slovakia and Hungary ${ }^{51}$, which facilitated close cooperation and mutual support. The potential impact of the Visegrád Group grew after the Lisbon Treaty entered into force, because under the Treaty it became vital to find allies in order to be successful in promoting new initiatives within the EU. Consultations on EU matters were held on a regular basis. Poland made use of this forum mainly to promote the notion of energy solidarity and Eastern Partnership issues. It also sought the Group's support on the climate package in 2009 and on issuing a joint statement to uphold EU spending on cohesion policy in the 2014-2020 perspective.

In view of the conflict in Ukraine, there were difficulties in effectively implementing the Visegrád Group formula as the states within the group differed in their reactions to Russia's policy and actions. Slovakia and Hungary, both strongly dependent on Russian natural gas, feared that excessive sanctions could be detrimental for their countries. In

\footnotetext{
${ }^{49}$ Szeptycki Andrzej: "Poland's Policy Regarding France", Yearbook of Polish Foreign Policy 2008, Warsaw, p. 119-122.

50 Parzymies Stanislaw: "François Hollande. Nowy architekt polityki zagranicznej Francji", Sprawy Międzynarodowe, 2012, No 2, p.55-78.

51 Between 1991 and 1993, the name was 'the Visegrád Triangle'.
} 
September, after a meeting with Vladimir Putin, the Czech president Miloš Zeman actually argued in favour of lifting the sanctions against Russia.

\section{Poland's Policy towards its Eastern Neighbours}

Relations with Russia, Ukraine and Belarus continue to present an important challenge for Polish foreign policy. Poland's objectives in this respect include: establishing a good relationship with Russia where both parties are treated as equal partners; further development of the relationship between Ukraine and the EU and NATO; and democratization in Belarus. Poland has also supported the Western leanings of Georgia and Moldova. As a country that has itself experienced a successful political transformation, it offered support for reforms, guided by the belief that stable rule of law in the neighbouring countries ensures Poland's security and contributes to a peaceful Europe ${ }^{52}$.

Relations with Russia (the successor of the USSR) became problematic when Poland attempted a westward shift in its policy post-1989. Russia opposed the expansion of the EU and NATO to include Poland. Its vision for the post-Soviet countries was different and relied on their very close relations with Moscow. Given the disparity of interests, relations between the two countries were rather poor.

There were several attempts at overcoming the historical problems; for instance, a body called Polish-Russian Group for Difficult Matters was formed ${ }^{53}$. Yet bilateral dialogue was much less advanced compared to similar discussions with Germany. Poland argued that Russia's cooperation was unsatisfactory in matters such as the investigation of Soviet crimes against Poles during World War II (mainly the crimes committed in Katyn, where in 1941 Polish civilian intellectuals and military officials fell victims to mass murders). Russia in turn criticized Poland's alleged disrespect towards the memory of the soldiers who died in the fight against the German oppressors.

Russia also had an unfavourable view of Poland's efforts in the area of security, in particular the invitation to the USA to place parts of the anti-missile defence system on Polish soil, or having NATO forces stationed within the country. Poland's involvement in Ukraine during the Orange Revolution in 2004 and in the subsequent years triggered sanctions: in 2005, Russia imposed sanctions to Poland, affecting Polish plant- and animal-based food products and, in retaliation, Poland vetoed the negotiations between the EU and Russia on a new treaty on mutual cooperation.

Donald Tusk's government endeavoured to improve the atmosphere. On 8 February 2008, Donald Tusk made the first official visit to Moscow in many years. It proceeded smoothly. Permanent mechanisms for cooperation were either established or re-established. They included a committee for Polish-Russian cooperation strategy, a Polish-Russian intergovernmental committee for economic cooperation, a forum for civic dialogue and a forum of regions.

The war between Russia and Georgia was an obstacle to friendly relations. Polish President Lech Kaczyński was particularly vocal in his criticism of it. The Polish foreign ministry issued an official statement saying that the violation of Georgia's territorial integrity by foreign military forces was unacceptable and criticizing the fact that Russia recognized South Ossetia's and Abkhazia's independence.

52 Priorytety Polskiej Polityki zagranicznej 2012-2016, p. 17.

53 The Polish-Russian Group for Difficult Matters was formed in 2002 but became operational in 2008. 
Nonetheless, the subsequent years brought several important meetings and agreements ${ }^{54}$. Vladimir Putin was present during the commemoration of the $70^{\text {th }}$ anniversary of the beginning of World War II in Westerplatte ${ }^{55}$ in Poland on 1 September 2009, and on 7 April 2010 together with Polish Prime Minister Donald Tusk he participated in the commemoration of the $70^{\text {th }}$ anniversary of the Katyn massacre. Moreover, on 26 November 2010, the Russian Duma adopted a resolution 'On the tragedy in Katyn and its victims', condemning the crime and assigning responsibility for it to Joseph Stalin and other Russian leaders.

Relations deteriorated again when the Polish airplane TU-154, carrying aboard the Polish president Lech Kaczyński along with a large entourage, crashed on 10 April 2010 near Smolensk. The plane was carrying the official Polish delegation travelling to commemorate the anniversary of the massacre in Katyn. There were 96 victims in the crash, including the President, his wife, and many key members of the government and public administration. Poland and Russia disagreed as to the reasons for the crash. Additionally, Russia was reluctant to hand over the wreckage of the airplane. The last official high-level Polish-Russian meeting in the recent years was when President Bronisław Komorowski and President Dmitry Medvedev met to honour the victims of the crash on its first anniversary, on 11 April 2011 in Smolensk and in Katyn.

The brief revival in mutual relations could not bridge the objectively contrary interests of the two states. This was particularly evident during the conflict in Ukraine. In the first phase of the crisis, Prime Minister Donald Tusk was a vocal proponent of imposing and maintaining sanctions against Russia. Relations practically dissipated and hostile rhetoric intensified. The Polish government decided to withdraw from its plans to celebrate 2015 as the year of Russia in Poland. Polish economy was affected by the Russian embargo on meat, dairy, fruit and vegetables originating in the EU (in February and August 2014) and by the ban on re-exporting plant-based products. In view of the continuing war in Ukraine, there appears to be no prospect of significant improvement in official Polish-Russian relations.

Ukraine holds an exceptional place in Polish foreign policy. Good neighbourly relations and the establishment of a special partnership between the two countries are two constant policy objectives. This view was reflected e.g. in the appointment of the Consultative Committee of the Presidents of Ukraine and of the Republic of Poland in Kiev on 12 January $1993^{56}$ and the adoption of the Declaration by the Foreign Ministers of the Republic and Poland and Ukraine on the Principles for Shaping the Polish-Ukrainian Partnership on 21 March $1994^{57}$. In this case, historical issues (in particular the interpretation of the massacres

\footnotetext{
54 For instance, an agreement on local transborder traffic with Kaliningrad Oblast wad adopted; it entered into force on 27 July 2012.

55 Vladimir Putin gave a speech in Westerplatte on 1 September, and an article authored by him was published in a major Polish daily Gazeta Wyborcza. The article discussed the interpretation of the Molotov-Ribbentrop Pact and other key events of World War II. The Polish interpretation of these historical events was presented by President Lech Kaczyński in another major daily Rzeczpospolita, also on 1 September, and by foreign minister Radosław Sikorki in Gazeta Wyborcza on 29 August. While noting its certain relativist elements, minister Radosław Sikorski argued that Vladimir Putin's narration 'offered a platform for further discussion'. The Polish government had an overall positive view of the fact that the Russian Prime Minister was present during the commemoration. See also: "Biuletyn z posiedzenia Komisji Spraw Zagranicznych z 23 września 2009 r.", No 2751/VI kad.

56 "Protokół o utworzeniu Komitetu Konsultacyjnego prezydentów Ukrainy i Rzeczpospolitej Polskiej," in: Zbiór Dokumentów No 1, 1993.

57 "Deklaracja ministrów spraw zagranicznych Rzeczpospolitej Polskiej i Ukrainy o zasadach kształtowania polsko-ukraińskiego partnerstwa, Warszawa, 21 marca 1994 r.", Zbiór Dokumentów No 1, 1994.
} 
in Volhynia and the perception of certain historical Ukrainian national heroes) were no obstacle to constructive development of mutual relations ${ }^{58}$.

Close cooperation with Poland was intended to consolidate Ukrainian independence and democracy, and then to support the pro-Western orientation in its politics. Ukraine's independence was perceived as a 'factor that encourages the consolidation of Poland's independence ${ }^{59}$. The intention was also that an independent Ukraine should be a democratic country that respects human rights (i.e. that its policies should conform to Western standards). In treaties and joint declarations, these values were unfailingly included among the foundations of the relations ${ }^{60}$. Polish politicians frequently stressed the importance of democracy and human rights in relations with Ukraine.

Polish authorities reacted strongly to violations of democratic principles during presidential elections in Ukraine in 2004. President Aleksander Kwaśniewski played an important role in dispelling the crises during the Orange Revolution, making a strong contribution to the attainment of an accord between the Ukrainian authorities and the opposition $^{61}$. He held talks with most European leaders to facilitate an understanding of the events in Ukraine and in support of democracy ${ }^{62}$. At first, the West remained aloof, fearing a deterioration of relations with Russia (which clearly demonstrated its preference for Viktor Yanukovych's victory) ${ }^{63}$.

Polish diplomacy also worked towards securing NATO membership for Ukraine. During the 2009 NATO summit in Bucharest, Poland argued in favour of a MAP (Membership Action Pland) for Ukraine and Georgia. However, Germany and France were thoroughly opposed to this idea, fearing Russia's reaction. Poland's efforts to ensure the MAPs proved unsuccessful, but the work of the Polish diplomacy - and the personal involvement of President Lech Kaczyński - resulted in the inclusion of a declaration of future membership of Ukraine and Georgia in the final documents of the summit. Poland pressed NATO to uphold its 'open doors' policy and continued to cooperate with Ukraine with regard to security and defence.

Poland had high hopes for the Eastern Partnership project, and Ukraine and Moldova had expressed a strong interest in the benefits it offered. However, in view of Ukraine's internal problems (after Viktor Yanukovych became president in February 2010) it became increasingly difficult to promote democracy and close ties with Europe. Despite numerous assurances made to President Bronisław Komorowski at bilateral meetings, President Viktor Janukowycz refused - to some extent due to the strong pressure from Russia - to sign an EU association agreement in Vilnius on 21 November 2013.

As the crisis in Ukraine progressed, mass demonstrations began on Kiev's Maidan, and violence was used against the demonstrators, Polish diplomacy was once again spurred into action. Aware that it has insufficient measures to respond on its own, Poland worked to secure

\footnotetext{
${ }^{58}$ Brzeziński, Ian J.: "Polish-Ukrainian Relations: Europe’s Neglected Strategic Axis", Survival, Vol. 35, No. 3, Autumn 1993, p.26-37.

59 See "Wspólna deklaracja Prezydentów Rzeczypospolitej Polskiej i Ukrainy, Warszawa, 25 czerwca 1996", Zbiór Dokumentów No. 2, 1996.

60 Ibidem, and also: "Wspólne oświadczenie Prezydentów Rzeczypospolitej Polskiej i Ukrainy o porozumieniu i pojednaniu, Kijów, 21 maja 1997 r" Zbiór Dokumentów No. 2, 1997 and others.

61 Also involved was Lithuanian President Valdas Adamkus. In the end, the international group of mediators also included Javier Solana, the EU's representative for CFSP, and OSCE Secretary General Jan Kubis. The Russian Federation was represented by Duma chairman Borys Gryzlov.

62 Ash, Timothy Garton, Snyder, Timothy: "The Orange Revolution," The New York Review of Books, Vol. 52 , No. 7, 28 April 2005.

63 See commentary by Ash, Timothy Garton in The Guardian, 2 December 2004.
} 
a united European response, and to ensure that the EU would constructively engage in the mediations between the Ukrainian authorities and the opposition and Maidan. The involvement of Prime Minister Donald Tusk and foreign minister Radosław Sikorski in early 2014 reinforced the image of Poland as a leader of EU's eastern policy ${ }^{64}$.

Overall, the reaction of the EU towards the escalation of the crisis was slow and indecisive. The EU was unprepared for the escalation of Russia's confrontational attitude towards Ukraine that led to the annexation ${ }^{65}$ and to military engagement in the east of Ukraine. Polish government officially condemned Russia for signing the treaty incorporating the Autonomous Republic of Crimea and Sevastopol into the Russian Federation ${ }^{66}$. The crisis in Ukraine revealed the weakness of Polish-Russian relations. While the Polish authorities communicated with all the parties to the crisis in Ukraine and with their European partners, they were unable to engage at all with their Russian counterparts. Poland was therefore not welcome at the negotiations on ending the Ukrainian conflict.

In view of the progressing conflict in Ukraine, Poland's policy was to support its territorial integrity and sovereignty, and to promote the development of its relationship with the EU. President Bronisław Komorowski signed the bill to ratify the UE-Ukraine association agreement on 17 December 2014. Poland also offered technical assistance and advisory services with regard to local government reform, anti-corruption measures and finance.

While promoting the democratic reforms it had itself undergone, Poland remained aware of its limitations, such as insufficient funding available for this purpose. Poland was also unable to overcome the disinterest of certain elites in the countries to its east with regard to building a closer relationship with Western institutions. This was particularly true with regard to Belarus, governed since 1994 by President Alexander Lukashenko. Despite the numerous diplomatic initiatives and despite the support provided to the civic society in Belarus, Polish involvement there must be considered unsuccessful. However, since democracy beyond its eastern borders is considered vital to Poland's overall security, this involvement will continue. The efforts in this regard are encouraged by the presence of Polish ethnic minorities both in Ukraine and in Belarus. The rights of these ethnic Poles would be best protected in democracies ${ }^{67}$.

\section{Beyond Europe}

Poland's involvement in its relations with non-European countries was limited. Given its medium size and capacity, Poland's diplomatic focus was on European, eastern, and transAtlantic policy.

Beyond Europe, Poland sought mainly to boost its international trade, $80 \%$ of which takes place within the EU. China has been Poland's biggest trading partner outside the EU, but the relationship is marked by a large deficit. President Bronisław Komorowski's visit to China resulted in a strategic partnership declaration, which elevated the relations between the

64 For example, Le Soir and Frankfurter Allgemeine Zeitung dated 25 February 2014; see also the annual report of the European Council on Foreign Relations in which Poland is named a leader of EU foreign policy, European Foreign Policy Scorecard 2014.

65 For an interesting analysis see: Speck, Ulrich: Has the EU Failed Ukraine? 21 February 2014, at http://carnegieeurope.eu/strategiceurope/?fa=54600.

66 Statement on the annexation of Crimea and Sevastopol to the Russian Federation dated 18 March 2014, at www.msz.gov.pl

${ }^{67}$ Bieńczyk-Missala, Agnieszka (2006):"Human Rights in Polish Foreign Policy after 1989", Warsaw , Polish Institute of International Affairs, p. 181-190. 
two countries to a new level in the subsequent years ${ }^{68}$. Poland endeavoured to encourage business with China by promoting Chinese cooperation with other Central and Eastern European states.

For the first time in 25 years, the Chinese prime minister visited Poland in March 2012. On that occasion, a meeting was organized in Warsaw with prime ministers and deputy prime ministers of 16 Central and Eastern European states ${ }^{69}$. These efforts continued in October 2012, when Poland organized a forum on cooperation between China and the Visegrád Group. This led to a strong boost in the number of contracts and joint business ventures. The new Polish President Andrzej Duda continued to work along similar lines, paying a 4-day visit to China in November 2015.

Poland's military involvement in the Middle East did not translate into a stronger economic presence in the region. Nonetheless, Poland pursued opportunities there, with a focus on alternative energy supply sources. This led to an agreement signed in June 2009 between Qatargas and the Polish energy operator PGNiG for the supply of liquefied natural gas, which is now being delivered into the new facility in Świnoujście.

Poland made certain endeavours to promote relations with India, Israel, Japan, South Korea, Mongolia and Turkey. In the recent years, Polish leaders have also visited several African and Latin American countries (South Africa, Nigeria, Peru and Chile).

Finally, countries outside Europe have received a large proportion of Polish developmental aid, offered as part of the work carried out by the UN, the OSCE and the EU to eradicate poverty worldwide. Aid from Poland has flowed mainly towards North and East Africa, Afghanistan, Kyrgyzstan, Tajikistan and the Palestinian Autonomy.

68 Polish-Russian relations are the eighth case of what China refers to as a strategic partnership in the EU.

69 The talks had their practically-oriented counterpart (generating direct networking opportunities) in the form of another event held on the same day: Economic Forum Poland - Central Europe - China, attended e.g. by businesspeople from China, Poland and other countries in the region. 